\title{
Phagosomal TLR signaling upon Borrelia burgdorferi infection
}

\author{
Jorge L. Cervantes ${ }^{1,2}{ }^{*}$, Kelly L. Hawley ${ }^{1,2}$, Sarah J. Benjamin ${ }^{1}$, Bennett Weinerman ${ }^{1}$, \\ Stephanie M. Luu ${ }^{3}$ and Juan C. Salazar ${ }^{1,2,4}$ \\ ${ }^{1}$ Department of Pediatrics, University of Connecticut Health Center, Farmington, CT, USA \\ 2 Division of Infectious Diseases, Connecticut Children's Medical Center, Hartford, CT, USA \\ ${ }^{3}$ Department of Molecular Biology and Biophysics, University of Connecticut Health Center, Farmington, CT, USA \\ ${ }^{4}$ Department of Immunology, University of Connecticut Health Center, Farmington, CT, USA
}

\section{Edited by:}

Tanja Petnicki-Ocwieja, Tufts

University School of Medicine and

Tufts Medical Center, USA

Reviewed by:

Ashu Sharma, University at Buffalo,

State University of New York, USA

Valerio lebba, 'Sapienza' University

of Rome, Italy

*Correspondence:

Jorge L. Cervantes, Department of

Pediatrics, University of Connecticut

Health Center, 263 Farmington Ave.,

Farmington, CT 06030, USA

e-mail:cervantes@uchc.edu
Internalization and degradation of live $\mathrm{Bb}$ within phagosomal compartments of monocytes, macrophages and dendritic cells (DCs), allows for the release of lipoproteins, nucleic acids and other microbial products, triggering a broad and robust inflammatory response. Toll-like receptors (TLRs) are key players in the recognition of spirochetal ligands from whole viable organisms (i.e., vita-PAMPs). Herein we will review the role of endosomal TLRs in the response to the Lyme disease spirochete.

Keywords: Borrelia burgdorferi, toll-like receptors, innate immunity, phagosomal signaling, Lyme disease

\section{INTRODUCTION}

Borrelia burgdorferi $(\mathrm{Bb})$, the causative agent of Lyme disease (Radolf et al., 2012) is the most prevalent vector-borne disease in North America (Levi et al., 2012). In nature, Bb persists asymptomatically in rodent reservoirs, such as the white-footed mouse Peromyscus leucopus (Barthold and Philip, 2010). Infection in humans is incidental, and probably represents a dead-end for the bacterium, as the spirochete is not well adapted to the human host.

Bb contains a complex bacterial genome (Fraser et al., 1997), and is composed of different strains and genospecies with differences in infectivity, host range, and tissue tropism (Schutzer et al., 2011; Yang et al., 2013). Different from gram-negative bacteria, Bb does not contain LPS (Takayama et al., 1987), and instead it has a number and variety of lipoproteins, many of them embedded on the spirochete's outer membrane (Bergstrom and Zückert, 2010). A number of well-known borrelial lipoproteins (e.g., OspA) are preferentially expressed at particular stages of the enzootic cycle (Radolf et al., 2012).

$\mathrm{Bb}$ also lacks any toxigenic molecules, thus, the clinical manifestations associated with Lyme disease are thought to result from the host's innate and adaptive immune response to the invading spirochete (Radolf et al., 2012). A great amount of research has been done trying to elucidate the mechanism by which $\mathrm{Bb}$ causes inflammation, which in some Lyme Disease patients manifests as severe arthritis, carditis, and/or central nervous system disorders (Radolf and Samuels, 2010). Initial studies focused on the role of Borrelia's abundant lipoproteins, which are capable of binding CD14 and Toll-like receptor (TLR) 2/TLR1 heterodimers on the surface of phagocytic cells to induce the production of inflammatory cytokines (Weiss, 2010;
Radolf et al., 2012). However, we and others have shown that internalization and degradation of live $\mathrm{Bb}$ by monocytes and macrophages within phagosomal compartments, allows for the release of lipoproteins and other microbial products, including RNA and peptidoglycan, eliciting a broader and more complex inflammatory response that can possibly take place on the cell surface of innate immune cells (Salazar et al., 2009; Cervantes et al., 2011). We have called this process "phagosomal signaling."

TLRs are transmembrane receptors which can recognize various pathogen-associated molecular patterns (PAMPs), including spirochetal lipoproteins and nucleic acids. The interaction between spirochetal PAMPs and the TLRs triggers a variety of intracellular signaling pathways leading to the production of various cytokines, including type I interferons (Salazar et al., 2009; Cervantes et al., 2011). This review focuses on the role of endosomal TLRs in Bb-mediated phagosomal signaling.

\section{B. BURGDORFERI INFECTION AND THE INNATE IMMUNE RESPONSE}

While studies have shown that neutralizing antibodies are important in host defense against $\mathrm{Bb}$ infection, the innate immune system is now known to have a critical role in spirochetal recognition and clearance from infected blood and tissues (Barthold et al., 1992). Monocytes, dendritic cells, macrophages, Natural Killer cells (NK-cells), NK-T cells, and polymorphonuclear cells (PMNs), all contribute to generate a coordinated and robust response to Bb infection (Salazar et al., 2003; Moore et al., 2007). We have proposed a model, where this response is initiated through recognition of specific Bb ligands during phagocytosis, primarily by the activation of endosomal TLRs (Moore et al., 2007; Petzke et al., 2009; Salazar et al., 2009; Cervantes et al., 
2011). In this section we will briefly describe the role of NKT cells, PMNs, monocytes/macrophages and DCs in spirochetal recognition.

\section{NATURAL KILLER T (NKT) CELLS}

NKT cells play an important role in the regulation of the inflammatory response during Bb infection (Lee et al., 2010). In one study, Bb-infected NKT-depleted-mice had greater inflammation in infected joint tissues, as well as decreased pathogen clearance (Tupin et al., 2008). This finding is not surprising, given that Antigen-presenting cells (APCs) activate NKT cells through presentation of a diacylglycerol glycolipid (Olson et al., 2009). Upon activation with $\mathrm{Bb}$, NKT cells upregulate of IFN $\gamma$ to activate and differentiate macrophages (Olson et al., 2009). It is not know whether NKT cells have a role in the pathogenesis of Lyme arthritis in humans.

\section{POLYMORPHONUCLEAR CELLS (PMNs)}

The neutrophil is an essential element of the inflammatory response to the Lyme disease spirochete in both skin and joints
(Salazar et al., 2003; Radolf and Samuels, 2010). Indeed, PMNs have been shown to play a significant role in the development of Lyme arthritis in experimentally infected mice (Nardelli et al., 2008; Codolo et al., 2013). In humans, PMNs are the primary cell type present in joint fluids from LD patients diagnosed with acute arthritis. PMNs are responsible for the production of several inflammatory cytokines, various chemokines, and stimulating factors that are likely to contribute to inflammation in the joints by inducing macrophage migration and differentiation and T-cell activation (Georgilis et al., 1991; Brown et al., 2003; Mantovani et al., 2011).

\section{MONOCYTES}

Monocytes are thought to have an important role in the production of proinflammatory cytokines during $\mathrm{Bb}$ infection (Salazar et al., 2009). Phagocytosis of Bb by human monocytes activates signaling cascades, which induce transcription of proinflammatory cytokines, including IL-6, TNF- $\alpha$, and IL-12 (Salazar et al., 2003; Cruz et al., 2008; Salazar et al., 2009)



FIGURE 1 | Innate signaling cascade in response to Bb Phagocytosis: Monocytes produce IL-12 to activate Th1 cells and IL6 and IL-1 $\beta$ to activate Th17 cells. Monocytes differentiate into macrophages when stimulated with IFN- $\gamma$ (produced by Th1 cells) and M-CSF (produced by Th17 cells) and differentiate into dendritic cells when stimulated with IL-4 and IFN- $\gamma$. M0 macrophages produce IL-18 to activate Th1 cells and IL-6 and IL-1 $\beta$ to activate Th17 cells, as well as several PMN recruitment chemokines. They also differentiate into M1 macrophages when stimulated with GM-CSF and IFN- $\gamma$. Dendritic cells produce IL-6, IL- $1 \beta$, and TGF- $\beta$ to activate Th17 cells. Th17 cells produce IL-17, which is a strong PMN attractant. Part of images from Motifolio drawing toolkit (www.motifolio.com) were utilized in the figure preparation. 
(Figure 1). IL-6 activates $\mathrm{T}$ helper cells and induces Th17 differentiation, which in turn can recruit PMNs through IL-17 production (Burchill et al., 2003). TNF- $\alpha$ has the ability to increase vascular permeability at the infection site, resulting in increased infiltration of PMNs and other innate immune cells. IL12 production by the monocytes is likely to induce Th1 differentiation and increased secretion of IFN $\gamma$ (Biswas and Mantovani, 2010). IFN $\gamma$ plays an important role in M1 macrophage differentiation at infection sites (Mosser and Edwards, 2008). Monocytes also upregulate pro-IL-1 $\beta$ in response to $\mathrm{Bb}$ (Cruz et al., 2008), which when cleaved into IL- $1 \beta$ by caspase- 1 can also induce Th17 differentiation (Chung et al., 2009). Bb is also known to induce monocyte inflammatory cell death through an intrinsic signaling pathway (Cruz et al., 2008), a mechanism which possibly leads to the recruitment of other immune cells to Bb-infected tissues.

\section{MACROPHAGES}

$\mathrm{Bb}$ phagocytosis by macrophages results in increased transcription of IL- $1 \beta$, IL-6, TNF- $\alpha$, and type I IFNs (Strle et al., 2009). Bb-infected macrophages also produce a number of PMNs chemoattractants, including CCL3, CCL4, CCL5, CXCL9, and CXCL10 (Gautam et al., 2012). Macrophages also produce IL18 in response to $\mathrm{Bb}$ infection (Dennis et al., 2006; Oosting et al., 2011), which in turn induces IFN $\gamma$ production by Th1 cells, driving M1 macrophage polarization (Mosser and Edwards, 2008). M1 macrophages upregulate iNOS and reactive oxygen species (Biswas and Mantovani, 2010), which are essential in clearance of Bb (Boylan et al., 2008). Phagocytosis of Bb by macrophages results in significant production of the antiinflammatory cytokine IL-10, to mediate resolution of the already initiated cytokine response, a phenomenon which may play a critical role in Lyme disease severity and arthritis development (Lazarus et al., 2008; Gautam et al., 2012; Chung et al., 2013).

\section{DENDRITIC CELLS (DCs)}

DCs are enriched in early Lyme disease skin lesions (erythema migrans) (Salazar et al., 2003) and are amongst the first immune cells to come into contact with Bb in the skin (Mason et al., 2014). Phagocytosis of $\mathrm{Bb}$ activates DCs by inducing expression of CD83 and upregulating expression of CD40, CD80, CD86, and HLADR (Suhonen et al., 2003) and lead to increased transcription of proinflammatory cytokines, including IL-6, IL- $1 \beta$, and TNF$\alpha$ (Petzke et al., 2009). TGF- $\beta$ is also produced by DCs after Bb infection, a cytokine which in turn induces Th17 differentiation (Chung et al., 2009). The PMN chemotactic factor IL-8 (Dennis et al., 2006), as well as a number of other PMN chemoattractants (Hartiala et al., 2007) are produced by DCs following Bb infection. Upon contact with $\mathrm{Bb}$ in the skin, DCs migrate to the lymph nodes where they present antigens to $\mathrm{T}$ cells and induce adaptive immune responses (Mason et al., 2014). Similarly to Bbstimulated macrophages, IL-10 is also elicited from Bb-infected DCs (Chung et al., 2013). IL-10 down-regulates macrophage activation, decreases the production of proinflammatory mediators, and suppresses phagocytosis-associated events that are important for mediating both innate and adaptive immune responses by APCs (Chung et al., 2013).

\section{MURINE vs. HUMAN}

The development of a murine model to study Lyme disease has greatly advanced our understanding of the cellular and humoral responses to $\mathrm{Bb}$. All inbred stains of laboratory mice are susceptible to $\mathrm{Bb}$ infection, although each strain differs in their disease severity. $\mathrm{C} 3 \mathrm{H} / \mathrm{He}$ and $\mathrm{Balb} / \mathrm{c}$ mice are more susceptible while $\mathrm{C} 57 \mathrm{BL} / 6$ and SJL mice tend to be more resistant to $\mathrm{Bb}$ infection (Barthold and Philip, 2010). Differences in the arthritis severity of these two strains might not involve discrepancies in bacterial clearance mechanisms, as both harbor similar numbers of spirochetes within their ankle joints (Ma et al., 1998). C3H cells have been reported to produce higher levels of NFK-B cytokines than C57BL/6 upon stimulation with purified borrelial lipoproteins (Ganapamo et al., 2003). However, differences in acquired immune responsiveness after whole $\mathrm{Bb}$ infection are still not well understood. Furthermore, studies on the role of NFאB-dependent cytokines in arthritis development have yielded conflicting results (Wooten and Weis, 2001). The susceptible strains produce higher IgG titers and tend to have more severe arthritis and carditis with similar manifestations to human infection (Barthold and Philip, 2010; Weiss, 2010). Importantly, no mouse strain develops the hallmark skin lesion erythema migrans caused by the inflammatory response elicited by the spirochetes, nor neurological disease, making the murine Lyme model an imperfect model for human Lyme disease. Rhesus monkeys infected with $\mathrm{Bb}$ develop neuroborreliosis and erythema migrans in addition to arthritis, thus making the disease most similar to human infection. Costs and difficulties in genetic manipulation make the murine model more commonly used over the primate model (Barthold and Philip, 2010; Radolf et al., 2012).

Lyme carditis is caused primarily by the infiltration of monocytes and macrophages in $\mathrm{Bb}$ infected mice (Weiss, 2010). The genetic background of the experimentally infected murine model influences the susceptibility to the development of carditis, although the root of the diversity remains unknown. IFN $\gamma$ has been shown to locally modulate Lyme carditis and enhance the phagocytic capacity of macrophages (Olson et al., 2009). Macrophages are a critical part of the response to $\mathrm{Bb}$, especially for the control of spirochetal numbers in the heart (Behera et al., 2006; Olson et al., 2009). In humans, symptomatic Lyme carditis is rare and usually resolves with antibiotic therapies (Krause and Bockenstedt, 2013), although recently it has been shown to be associated with mortality rates higher than previously reported (CDC, 2013).

The field of Lyme arthritis has gained much insight from the use of $\mathrm{C} 3 \mathrm{H}$ mouse models due to the robust phenotype that mimics much of human Lyme disease arthritis complications (Barthold and Philip, 2010). However the spectrum of pathology observed in humans is not observed in the murine model (Steere et al., 1987). It has also been reported that there is a lack of $\mathrm{T}$ cell involvement in mice, which is contradictory to the observations of some human patient reports, suggesting the importance of Th1 and $\gamma / \delta$ T cells (Duray, 1989; Vincent et al., 1996; Gross et al., 1998; Roessner et al., 2003). A select 
group of Lyme arthritis patients experience persistent arthritis even following an appropriate course of antibiotic therapy (Shin et al., 2007). Investigation of this cohort of patients' synovial fluid suggests there is a possible dysregulated inflammatory response that presents with increased IL-1 $\beta$, IL-6, and IFN $\gamma$ (Shin et al., 2007) and chemokines CXCL9 and CXCL10 (Shin et al., 2007). IFN-responsive genes have been reported to be strongly up-regulated within the joints of $\mathrm{Bb}$-infected $\mathrm{C} 3 \mathrm{H}$ mice, but not in mildly arthritic C57BL/6 mice (Crandall et al., 2006). Nevertheless, bone marrow-derived macrophages from both $\mathrm{C} 3 \mathrm{H}$ and $\mathrm{C} 57 \mathrm{BL} / 6$ mice induce IFN-responsive genes following $\mathrm{Bb}$ stimulation (Miller et al., 2008a), and this expression appears to require a functional type I IFN receptor (Miller et al., 2008b). The arthritis observed in C57BL/6 mice is modulated by the production of IL-10 from CD4 ${ }^{+} \mathrm{T}$ cells and macrophages (Lazarus et al., 2008). IL-10 regulates the expression of IFN $\gamma$ and production of CXCL9 and CXCL10 (Lazarus et al., 2008; Sonderegger et al., 2012), and produce a similar phenotype of persistent arthritis patients (Shin et al., 2007).

TLR expression varies slightly between humans and mice, with ten human TLRs, and twelve murine functional TLRs identified to date (Gosu et al., 2012). TLR1-9 are conserved between the two species (Kawai and Akira, 2010). TLR8 is non-functional in mice because it lacks five amino acids (Liu et al., 2010). However, recently, a murine model expressing functional human TLR8 on a C57BL/6 background has been generated (Guiducci et al., 2013). TLR10 is also non-functional in mice due to a retrovirus insertion (Gosu et al., 2012). TLR11-13 are present in mice, but absent in humans (Kawai and Akira, 2010). In humans, TLR7 is mainly co-expressed with TLR9 on B cells and plasmacytoid DCs and TLR8 is nearly absent in this cell line; whereas TLR8 is highly expressed on monocytes/macrophages and myeloid DCs (Hornung et al., 2002; Cervantes et al., 2012). Differences in the inflammatory responses to $\mathrm{Bb}$ observed between human and mice, could be explained by variations in TLR- signaling (Petnicki-Ocwieja et al., 2013). Newly generated humanized mouse models would allow for future studies regarding the role of human TLRs in Lyme disease clinical manifestations and severity of disease.

\section{PHAGOCYTOSIS OF B. BURGDORFERI}

Phagocytosis is an important component of innate immunity to the Lyme disease spirochete. Uptake and degradation of the bacterium results in the induction of intracellular signals leading to the generation of cytokines, antigen processing and presentation, which ultimately leads to the development of acquired immunity (Greenberg and Grinstein, 2002; Moore et al., 2007).

Delivering individual PAMPs in experimental systems fails to mimic the natural processes of innate immune activation by TLRs in response to a live organism. In the case of endosomal TLRs, ligands are usually delivered in a complex with a cationic polymer such as polyethylenimine or DOTAP (Cervantes et al., 2013; Love et al., 2014). The natural agonists for endosomal TLRs are, however, an integral part of live pathogens and as such, are not directly accessible to receptors but after the whole organism has been degraded in the endolysosomal compartment (Vance et al., 2009). The immune system responds more robustly to viable microorganisms than it does to dead organisms. Blander and colleagues found that viable bacteria, but not killed ones, contain a class of PAMPs which they coined as vita-PAMPs (Sander et al., 2011). These vita-PAMPs, such as mRNA, signify microbe viability to the innate immune system (Sander et al., 2011). Pathogen and host cell-derived material associated with pathogen nucleic acids have to be taken up into the endolysosomal compartment, where degradation allows the nucleic acids to become available for TLR binding. The detection of vita-PAMPs and conventional PAMPs could interact with multiple PRRs within the phagosome and/or the cytosol and have a crucial role in antimicrobial immunity (Sander et al., 2011).

Professional immune phagocytes, such as monocytes, macrophages, DCs (Benach et al., 1984a; Filgueira et al., 1996; Moore et al., 2007) as well as other various cell types (ex. murine microglia, chondrocytes, synovial, and L929 fibroblast) have been demonstrated to internalize Bb (Franz et al., 2001; Kuhlow et al., 2005; Behera et al., 2008; Chmielewski and Tylewska-Wierzbanowska, 2010). The initiation of phagocytosis requires interaction of phagocytic receptors (other than CD14 and TLRs) located on the surface of innate immune cells with surface molecules of Bb innate immune cells (Shin et al., 2008; Sahay et al., 2009), and internalization of Bb by murine, rat and rabbit macrophages can occur in the presence (Fc-mediated phagocytosis) (Figure 2A) or absence of opsonic antibodies (Figure 2B) (Benach et al., 1984b; Montgomery et al., 1994). Bb is able to activate both the classical and alternative complement pathways (Kochi and Johnson, 1988). C3b can either bind to the surface of bacteria and facilitate internalization of the spirochete by opsonization or $\mathrm{C} 3 \mathrm{~b}$ or proceed to membrane attack complex formation and lysis of the bacteria by depositing downstream components into the cell wall. The spirochete has evolved mechanisms that enable them to evade complemented-mediated lysis (Fraser et al., 1997), such as expression of complement regulator-acquiring surface proteins (CRASPs). CRASPs act as binding sites for the complement inhibitor factor $\mathrm{H}$ and factor H-like protein (Hellwage et al., 2001; Kraiczy et al., 2001, 2004) and cleave bound serum complement protein $\mathrm{C} 3 \mathrm{~b}$ into the serum opsonin inactivated C3b (iC3b) (Figure 2A).

Complement Receptor 3 (CR3) (integrin $\alpha_{M} \beta_{2}$, $\mathrm{CD} 11 \mathrm{~b} / \mathrm{CD} 18)$ was demonstrated to directly bind $\mathrm{Bb}$ and the presence of complement enhanced spirochetal binding (Cinco et al., 1997; Garcia et al., 2005). ICAM-1, iC3b and fibrinogen, known CR3 protein ligands, have been shown to interact with the I-domain of CR3 (Humphries, 2000). Only recently, Hawley et al. identified CR3 to be a phagocytic receptor in murine macrophage and human monocyte (Figure 2B). This study revealed that CR3 requires cooperation of the GPI-anchored protein, CD14 for the internalization of unopsonized $\mathrm{Bb}$ and that CR3-mediated phagocytosis of $\mathrm{Bb}$ occurs in a Myeloid differentiation primary response gene 88 (MyD88)-independent manner, thus suggesting the involvement of additional receptors in MyD88-dependent $\mathrm{Bb}$ phagocytosis (Hawley et al., 2012). CD14 is involved in translocation of CR3 to the lipid rich microenvironments known as lipid rafts following interaction with live Bb (Hawley et al., 2013). The findings suggest that CD14 interacts with the C-lectin domain of the integrin to induce crosslinking of the integrin and 


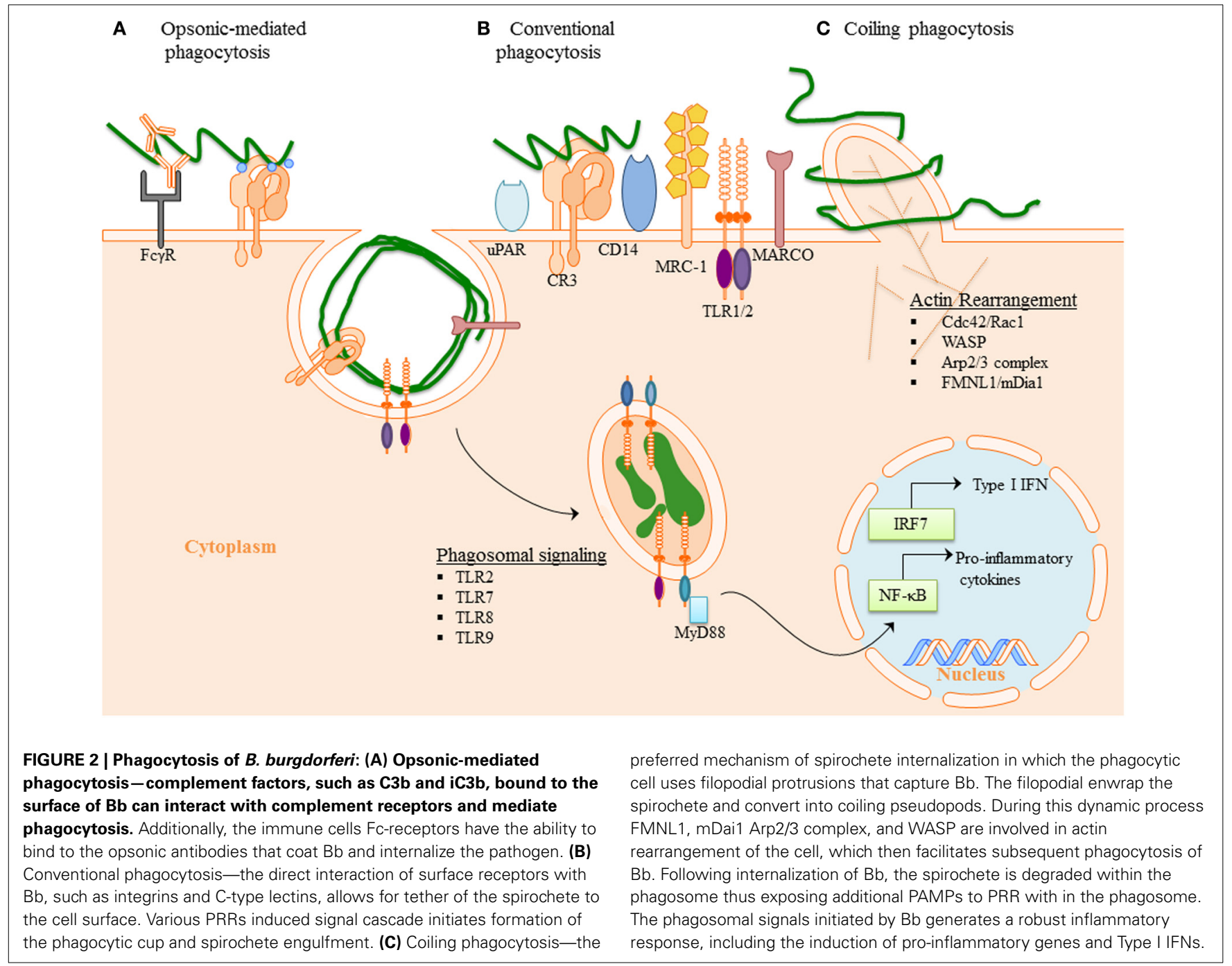

efficient internalization of Bb. Additionally, MyD88-independent inflammatory pathways have been reported following interaction of the spirochete with the integrin $\alpha_{3} \beta_{1}$ on primary human chrondrocytes and may be a mechanism directly relevant to the development of arthritis (Behera et al., 2008). Moreover, urokinase receptor ( $\mathrm{UPAR}, \mathrm{CD} 87$ ) has been shown to facilitate clearance of $\mathrm{Bb}$ (Figure 2B), and provides an area for additional investigation as to the mechanistic involvement in bacterial clearance (Hovius et al., 2009).

Scavenger receptors comprise a group of unrelated transmembrane surface molecules with relatively promiscuous ligand binding such as scavenger receptor A (SR-A), MARCO (Macrophage receptor with Collagenouse structure) and CD36 (Areschoug and Gordon, 2009). This promiscuity allows scavenger receptors to mediate uptake of a wide range of pathogens including bacteria (Peiser et al., 2000; Thelen et al., 2010), yeast, viruses and parasites (Mukhopadhyay and Gordon, 2004), as well as removal of dead cell material by both macrophages and DCs (Brencicova and Diebold, 2013). Little is known about their natural ligands and the structural basis for ligand binding of bacteria. CD36 and MARCO can interact with TLR2 and CD14, regulating NFK-B

cytokine responses (Bowdish et al., 2009; Jordo et al., 2011). MARCO expression appears to be MyD88 dependent in mice, and MARCO mediated phagocytosis of $\mathrm{Bb}$ seems an important mechanism for TRIF signaling (Petnicki-Ocwieja et al., 2013). The mannose receptor has been demonstrated to bind to $\mathrm{Bb}$ (Cinco et al., 2001), but its role in Bb phagocytosis has not yet been investigated. Unlike the mannose receptor or CR3 that reconstitute phagocytosis in non-phagocytic cells, expression of SRA or MARCO confers only binding, without significant internalization of Gram positive or Gram negative bacteria (Underhill and Ozinsky, 2002). In macrophages, the scavenger receptors MARCO and SR-A are involved in uptake of CpG ODN and influence TLR9-mediated IL-12 induction with MARCO enhancing its production (Jozefowski et al., 2006).

Coiling phagocytosis is the preferred mechanism of $\mathrm{Bb}$ uptake, accounting for approximately 60 to $70 \%$ of phagocytosis (Rittig et al., 1992, 1998; Naj et al., 2013). Coiling phagocytosis was first described as the phagocytic mechanism used to internalized Legionella pneumophila (Horwitz, 1984) where a unilateral pseudopod bends around the bacteria in a hook like fashion. Phagocytosis is a complex mechanism where F-actin 
polymerization occurs to reorganize the membrane to internalize Bb (Chimini and Chavrier, 2000; Cruz et al., 2008). The Rho GTPases, Cdc42 and Rac1 regulate the actin dynamics (Chimini and Chavrier, 2000; Linder et al., 2001). WASP (Wiskott-Aldrich syndrome protein) and the Arp2/3 complex are mostly involved in branched actin network, to reorganize to the pseudopod intertwining $\mathrm{Bb}$ (Amann and Pollard, 2001; Higgs and Pollard, 2001; Linder et al., 2001) (Figure 2C). The formins, FMNL1 and $\mathrm{mDia} 1$, are actin nucleating proteins that influence formation of unbranched actin filaments and regulate coiling phagocytosis of $\mathrm{Bb}$ by primary human macrophages (Naj et al., 2013). In neutrophils, mDial is required for both CR3-mediated and Fc $\gamma \mathrm{R}$ mediated phagocytosis (Shi et al., 2009).

Much focus has been directed to the downstream signals initiated by TLRs following internalization of $\mathrm{Bb}$, especially those involving the adaptor molecule MyD88. Mice deficient in MyD88 have increased bacterial burdens but normal antibody production in comparison to wild-type (WT) mice infected with Bb (Liu et al., 2004). MyD88 deficient macrophages have a significant defect in their phagocytic ability of $\mathrm{Bb}$, roughly $50 \%$ reduction compared to the WT macrophages, supporting observations with phagocytosis and killing of bacteria, rather than a previously suggested defect in degradation in phagolysosome (Blander and Medzhitov, 2004; Yates and Russell, 2005; Shin et al., 2009).

\section{PHAGOSOMAL RECOGNITION OF B. BURGDORFERI LIGANDS}

Although there is plenty of evidence showing that formerly "outer membrane-associated TLRs" such as TLR2 and TLR4 are also recruited to the endosome (McGettrick and O'Neill, 2010; Gangloff, 2012; Brandt et al., 2013), the classic "endosomal nucleic acid-sensing TLRs” comprises TLR3, TLR7, TLR8, and TLR9 (Brencicova and Diebold, 2013). TLR 7, TLR8, and TLR9 depend on the endoplasmic reticulum (ER)-resident protein UNC93B1 for trafficking from the ER via the Golgi to the endolysosomal compartment (Brinkmann et al., 2007; Kim et al., 2008; Lee et al., 2013). UNC93B1 physically associates with the endosomal TLR (McGettrick and O'Neill, 2010; Itoh et al., 2011) and it appears to be essential for TLR8-mediated signaling (Itoh et al., 2011). Other factors involved in endosomal TLR trafficking are the ER chaperone GP96 and PRAT4A (McGettrick and O'Neill, 2010; Lee et al., 2013). Furthermore, trafficking of endosomal TLRs is also affected by recruitment of adaptor protein complexes, which are not only TLR-specific (Lee et al., 2013) but cell specific as well (Sasai et al., 2010; Henault et al., 2012).

Although originally associated with the recognition viral pathogens, endosomal TLRs are also able to sense bacterial nucleic acids. The earliest evidence for such recognition was done using TLR7 and TLR8-stably transfected HEK cell lines, showing that Escherichia coli total RNA induced activation of TLR7 and TLR8 (Kariko et al., 2005). More recent experimental evidence confirms that TLR7 is capable of sensing bacterial RNA in both human and murine DCs, inducing the production of several NFK-B cytokines (Eberle et al., 2009; Mancuso et al., 2009). A similar role for TLR8 activation, triggered by recognition of borrelial RNA delivered to endosomal vacuoles in human monocytes, was recently demonstrated by our group (Cervantes et al., 2013). The role of TLR8 in nucleic acid sensing was initially suggested by results from two previous studies reporting TLR8 upregulation after phagocytosis of Mycobacterium bovis (Davila et al., 2008), and Helicobacter pylori by THP-1 cells (Gantier et al., 2010). In our own studies we first showed that phagocytosis of live Borrelia burgdorferi by human monocytes (Figure 3) induces transcription of IFN- $\beta$ (Salazar et al., 2009), and subsequently confirmed that this phenomenon was entirely dependent on TLR8 (Cervantes et al., 2011), through IRF-7; a signaling pathway traditionally associated with recognition of viral RNA (Boo and Yang, 2010).

Type I interferon responses following phagocytosis of live $\mathrm{Bb}$ are not restricted to IFN- $\beta$ transcription by monocytes. In pDCs, production of IFN- $\alpha$ involves recognition of Bb ligands by TLR7 and TLR9 (Petzke et al., 2009; Love et al., 2014). In this cell type, IFN-responsive genes seem to be induced by Bb RNA through TLR7 recognition (Love et al., 2014).

Bacterial ribosomal RNA appears to be the major PAMP responsible for the production of IFN $-\alpha$ by human PBMCs (Eberle et al., 2009). Transfer RNA from some bacteria may also induce production of IFN- $\alpha$ through TLR7 activation (Jockel et al., 2012). In the case of Gram positive bacteria, such as Group

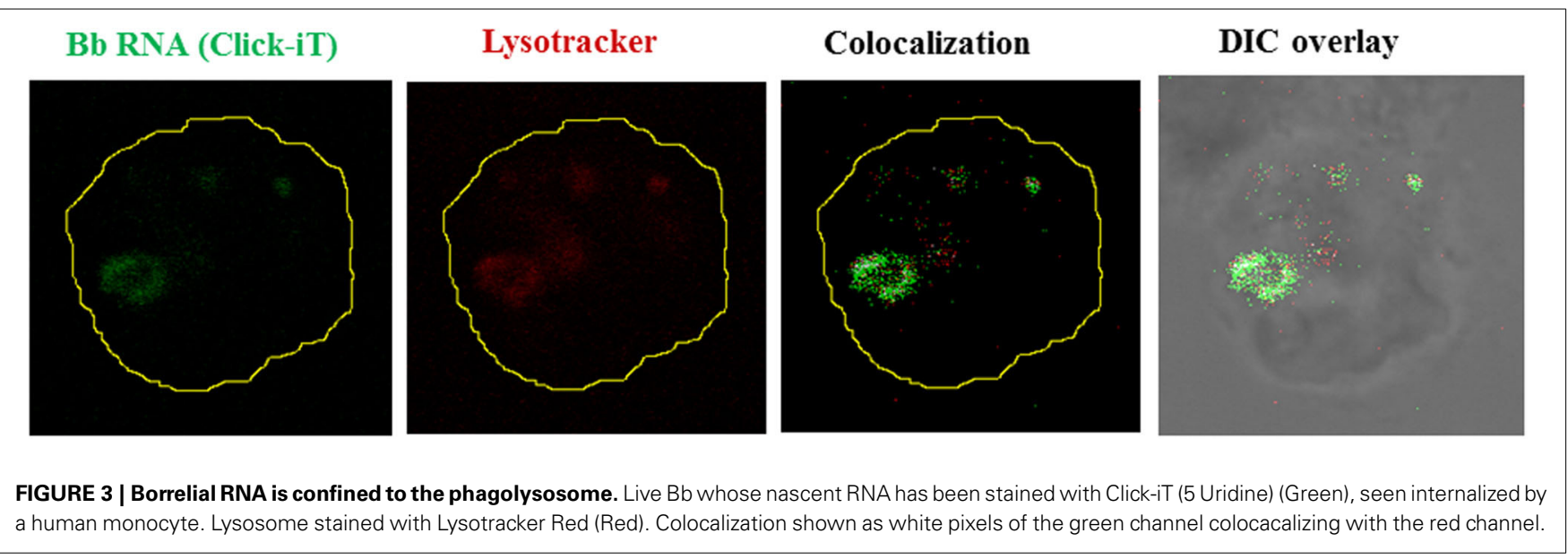


B Stretptococci, bacterial ssRNA is recognized in macrophages by a TLR-MyD88-UNC93B1 complex (Deshmukh et al., 2011).

\section{ENDOSOMAL TLR INVOLVEMENT IN AUTOIMMUNITY AND Bb NUCLEIC ACID PERSISTENCE}

Although the immune system has evolved mechanisms to prevent stimulation by self-nucleic acids, nucleic acid-sensing TLRs can trigger innate immune activation resulting in induction of autoimmunity (Saitoh and Miyake, 2009; Brencicova and Diebold, 2013). In fact TLR7, TLR8, and TLR9 are unable to distinguish between pathogen and self-nucleic acids on the basis of their molecular structures (Diebold et al., 2004; Heil et al., 2004; Barbalat et al., 2011). Mouse TLR7, and human TLR7 and TLR8 serve as PRR for single-stranded RNA (ssRNA), whereas the functionality of mouse TLR8 is still somewhat obscure (Cervantes et al., 2012). Presence of methylated nucleosides or pseudouridines in mammalian tRNA may also prevent TLR7 and TLR8 activation (Kariko et al., 2005). However, these nucleotide modifications are less frequent in mammalian mRNA (Maden and Hughes, 1997), which can become immunostimulatory when delivered to the endosome in form of complexes with polycations such as polyethylenimine (Koski et al., 2004; Kariko et al., 2005; Diebold et al., 2006).

TLR7 and TLR8 have already been shown to play a central role for the recognition of self RNA in the immunopathogenesis of autoimmune diseases such as systemic lupus erythematosus (SLE), psoriasis, rheumatoid arthritis, Sjögren's syndrome and others (Demaria et al., 2010; Zheng et al., 2010; Theofilopoulos et al., 2011). Human TLR8 inhibits TLR7 and TLR9 activation (Guiducci et al., 2013), and murine TLR8 also inhibits TLR7 activation (Wang et al., 2006). TLR8 deficiency leads to overexpression of TLR7 in murine DCs with increased NFK-B activation and development of autoimmunity (Demaria et al., 2010). In humans, TLR7 and TLR9 are upregulated in patients with Sjogren's syndrome (Zheng et al., 2010). Similarly, genetic modifications that lead to a duplication of the TLR7 gene or over-expression of transgenic TLR7 are associated with exacerbated lupus-like symptoms in murine models (Pisitkun et al., 2006; Deane et al., 2007). It is worth noting that TLR7 is located on the X chromosome and that females induce higher levels of IFN- $\alpha$ in response to TLR7 agonists (Berghofer et al., 2006), which could represent a major factor responsible for the higher prevalence of SLE in women.

One of the more puzzling aspects of Lyme disease is the persistence, in some patients, of musculoskeletal symptoms following $\mathrm{Bb}$ infection, and their refractoriness to rapid improvement despite proper antibiotic treatment (Bockenstedt et al., 2012). While erythema migrans and Lyme carditis often present within the first few weeks of intection, Lyme arthritis more often presents several weeks after the initial infection in untreated patients and can persist even after antibiotic treatment (Kean and Irvine, 2013). Since initial studies failed to detect spirochetal DNA in human synovial fluid following antibiotic treatment in LD with persistent arthritis, also called antibiotic-resistant Lyme arthritis, it was considered an autoimmune disease (Benoist and Mathis, 2001; Steere, 2012), possibly mediated by shedding of borrelial outer surface lipoproteins (Osps) within the synovial fluid (Batsford et al., 2004). However, in recent studies, investigators were able to detect $\mathrm{Bb}$ DNA in joint fluid from Lyme arthritis patients who received appropriate antibiotic therapy (Picha et al., 2008; Li et al., 2011; Picha et al., 2014). Bb positive PCR results have been reported to persist for as long as 11 months in patients with antibiotic-refractory arthritis, although detection of $\mathrm{Bb}$ DNA did not translate into active joint disease ( $\mathrm{Li}$ et al., 2011). DNA and antigen deposits have been shown to persist after antibiotic treatment in cartilage of mice deficient in MyD88 (Bockenstedt et al., 2012). This mouse strain exhibits more severe arthritis than WT (Bolz et al., 2004; Liu et al., 2004), and presents higher levels of IFN- $\beta$ in joint tissue after infection (Petnicki-Ocwieja et al., 2013).

Naked pathogen-derived nucleic acids present in the extracellular space upon release from damaged or disintegrated microbes or the infected host cells, may be ultimately degraded by extracellular DNases and RNases before they can access the endolysosomal compartment of other immune cells (Brencicova and Diebold, 2013). If such degradation fails to occur, the presence of this remaining nucleic acid could potentially trigger an autoimmune response. This has been shown to occur with released self-DNA in SLE patients carrying mutations in DNase I (Yasutomo et al., 2001), and in DNase I-deficient mice, which develop a lupus-like disease (Napirei et al., 2000). It has been hypothesized that the sensing of naked ssRNA and DNA, which is not associated with pathogen-derived material including nonnucleic acid PAMP, doesn't allow for the discrimination between pathogen-associated vs. self-nucleic acids and, therefore, has the potential to lead to autoimmunity (Brencicova and Diebold, 2013). Mechanisms that aid in the discrimination between foreign (pathogenic) and self (cellular) nucleic acids, aim to inhibit endosomal TLR activation, or prevent cellular nucleic acid to bind to endosomal TLRs. These mechanisms include the presence of modified RNA species such as tRNA and rRNA in total cellular nucleic acids (Kariko et al., 2005), sequestration of cellular nucleic acids through binding to cellular components, and/or recruitment of nucleic acid-sensing TLR to the endolysosomal compartment or their functional activation by cleavage, a process that may be regulated by gatekeeper receptors with the ability to detect PAMP and/or DAMP absent from uninfected cells (Brencicova and Diebold, 2013). Hence, any mechanisms that allow for or promote the recognition of naked ssRNA and DNA such as in the form of immune complexes should be regarded as non-physiological events.

TLR9 is another endosomal TLR that has been linked to autoimmunity (Theofilopoulos et al., 2011), and a potential role for TLR9 in recognition of Bb DNA may exist (data not shown). Initially, it was thought that TLR9 is located in the ER in unstimulated cells and is recruited to the endolysosomal compartment only after uptake of TLR9 agonist (Latz et al., 2004). However, there is evidence of steady-state low level of trafficking of nucleic acid-sensing TLR via the Golgi to the endolysosomal compartment which may initiate TLR recruitment upon stimulation with nucleic acids (Brencicova and Diebold, 2013).

\section{POTENTIAL ROLE OF TLR IN CLINICAL DISEASE SEVERITY}

While TLRs are capable of sensing pathogenic materials, defective TLR signaling can hinder activation of the adaptive response. 
On the other hand, excessive response of TLRs and production of cytokines may increase the disease state (Kean and Irvine, 2013).

$\mathrm{Bb}$ produces many symptoms within the human host, including erythema migrans, systemic inflammation, Lyme arthritis, Lyme carditis, and neuroborreliosis (Radolf et al., 2012; Kean and Irvine, 2013). It is now known that lipoproteins can serve as potent ligands for TLRs. Bb has many Osps that are capable of triggering the innate immune system through activation of TLRs (Gondolf et al., 1994; Radolf et al., 2012). The three major Osps of $\mathrm{Bb}$ include OspA, OspB, and OspC. Moreover, the CD14/TLR2 complex be activated by these lipid moieties. Using a rat model Batsford et al. showed that polymerized peptide OspA produced a short lasting arthritis and that lipidated OspA and OspA elicited severe arthritis (Batsford et al., 2004). Other studies have demonstrated that macrophages play a direct role in the induction of Lyme arthritis in hamsters (DuChateau et al., 1999). These facts implicate TLRs as key players in the development of Lyme arthritis and critical receptors for recognition of vita-PAMPs.

Borrelia infection can also lead to Lyme carditis, a dangerous condition that can in rare instances can lead to sudden death (CDC, 2013). The mechanism of Lyme carditis has been shown to involve invariant NKT cells (iNKT cells) (Olson et al., 2009). This type of cell can be activated by bacterial infection through TLR4, TLR7 and TLR9-driven maturation of dendritic cells (Brigl et al., 2003). Mice deficient in iNKT cells developed significantly worse inflammation in the heart following during $\mathrm{Bb}$ infection (Olson et al., 2009). iNKT cells localize to the inflamed heart, enhancing macrophage phagocytosis through IFN $\gamma$ leading to control of infection (Olson et al., 2009).

With recent progress in DNA analysis, the extremely polymorphic genes of TLRs can finally be understood. The genetic variability in TLRs can result in functional deficiency, which ultimately leads to immunodeficiency syndromes. The TLR1 1602S polymorphism, found predominantly in European-Caucasian populations, has been correlated with low expression of TLR1 at the surface membrane (Kean and Irvine, 2013). This mutation results in a diminished response to OspA due to the decreased capability of TLR2 to couple with TLR1, thus leading to an increased susceptibility to Lyme disease (Kean and Irvine, 2013). Individuals with mutations in the TLR2 gene, specifically Arg753Gln, are less responsive to PAMPs derived from $\mathrm{Bb}$ (Schwartz and Cook, 2005).

TLR signaling alterations have been linked to more severe clinical manifestations in response to bacterial, fungal and viral infections (Frazao et al., 2013). For instance, single nucleotide polymorphisms (SNPs) found within TLR7 have been associated with more severe Hepatits $\mathrm{C}$ viral infection (Lin et al., 2012). Mutations in the TLR 8 gene have been linked to increased susceptibility to bacterial infections (Davila et al., 2008). Other mutations can occur downstream of TLR-signaling. For example, deficiencies in MyD88 and IRAK4 result in impaired production of pro-inflammatory cytokines following TLR stimulation (Cervantes et al., 2013), and increased susceptibility to bacterial infections (Kenny et al., 2009; Netea et al., 2012).

It is important to note that despite the large number of TLR gene mutations found in the general population, most affected individuals will not suffer life threatening complications or even more severe infections than their unaffected counterparts (Netea et al., 2012). One explanation for the high rate of TLR polymorphism without increase in pathogen susceptibility is the redundancy of the innate and adaptive immune system. The high degree of nucleotide polymorphism seen in TLRs is consistent with the constant "arms race" driven by the rapidly evolving pathogens. Additionally, the lack of reproducibility among many experiments, in conjunction with small sample sizes of people with such phenotypes hints at the large genetic diversity among TLRs (Lin et al., 2012).

Future studies will attempt to elucidate the relationship between TLR mutations and the short and long-term outcome of human Lyme disease, particularly as to changes in these key innate immune receptors have a role in patients with prolonged, antibiotic refractory Lyme disease.

\section{ACKNOWLEDGMENTS}

This work was supported by NIAID grant AI090166, and Connecticut Children's Medical Center's (CCMC) Arrison and Burr Curtis Research Funds.

\section{REFERENCES}

Amann, K. J., and Pollard, T. D. (2001). The Arp2/3 complex nucleates actin filament branches from the sides of pre-existing filaments. Nat. Cell Biol. 3, 306-310. doi: 10.1038/35060104

Areschoug, T., and Gordon, S. (2009). Scavenger receptors: role in innate immunity and microbial pathogenesis. Cell. Microbiol. 11, 1160-1169. doi: 10.1111/j.14625822.2009.01326.x

Barbalat, R., Ewald, S. E., Mouchess, M. L., and Barton, G. M. (2011). Nucleic acid recognition by the innate immune system. Annu. Rev. Immunol. 29, 185-214. doi: 10.1146/annurev-immunol-031210-101340

Barthold, S. W., and Philip, M. T. (2010). "Animal models of Lyme borreliosis," in Borrelia: Molecular Biology, Host Interaction, and Pathogenesis, eds D. D. Samuels and J. D. Radolf (Norfolk: Caister Academic Press), 359-411.

Barthold, S. W., Sidman, C. L., and Smith, A. L. (1992). Lyme borreliosis in genetically resistant and susceptible mice with severe combined immunodeficiency. Am. J. Trop. Med. Hyg. 47, 605-613.

Batsford, S., Dunn, J., and Mihatsch, M. (2004). Outer surface lipoproteins of Borrelia burgdorferi vary in their ability to induce experimental joint injury. Arthritis Rheum. 50, 2360-2369. doi: 10.1002/art.20337

Behera, A. K., Durand, E., Cugini, C., Antonara, S., Bourassa, L., Hildebrand, E., et al. (2008). Borrelia burgdorferi BBB07 interaction with integrin alpha3betal stimulates production of pro-inflammatory mediators in primary human chondrocytes. Cell. Microbiol. 10, 320-331. doi: 10.1111/j.1462-5822.2007.01043.x

Behera, A. K., Hildebrand, E., Bronson, R. T., Perides, G., Uematsu, S., Akira, S., et al. (2006). MyD88 deficiency results in tissue-specific changes in cytokine induction and inflammation in interleukin-18-independent mice infected with Borrelia burgdorferi. Infect. Immun. 74, 1462-1470. doi: 10.1128/IAI.74.3.14621470.2006

Benach, J. L., Fleit, H. B., Habicht, G. S., Coleman, J. L., Bosler, E. M., and Lane, B. P. (1984b). Interactions of phagocytes with the Lyme disease spirochete: role of the Fc receptor. J. Infect. Dis. 150, 497-507. doi: 10.1093/infdis/150.4.497

Benach, J. L., Habicht, G. S., Gocinski, B. L., and Coleman, J. L. (1984a). Phagocytic cell responses to in vivo and in vitro exposure to the Lyme disease spirochete. Yale J. Biol. Med. 57, 599-605.

Benoist, C., and Mathis, D. (2001). Autoimmunity provoked by infection: how good is the case for T cell epitope mimicry? Nat. Immunol. 2, 797-801. doi: 10.1038/ni0901-797

Berghofer, B., Frommer, T., Haley, G., Fink, L., Bein, G., and Hackstein, H. (2006). TLR7 ligands induce higher IFN-alpha production in females. J. Immunol. 177, 2088-2096.

Bergstrom, S., and Zückert, W. R. (2010). "Structure, function, and biogenesis of the cell envelope," in Borrelia: Molecular Biology, Host Interaction, and 
Pathogenesis, eds D. S. Samuels and J. D. Radolf (Norfolk: Caister Academic Press), 139-166.

Biswas, S. K., and Mantovani, A. (2010). Macrophage plasticity and interaction with lymphocyte subsets: cancer as a paradigm. Nat. Immunol. 11, 889-896. doi: 10.1038/ni.1937

Blander, J. M., and Medzhitov, R. (2004). Regulation of phagosome maturation by signals from toll-like receptors. Science 304, 1014-1018. doi: 10.1126/science. 1096158

Bockenstedt, L. K., Gonzalez, D. G., Haberman, A. M., and Belperron, A. A. (2012). Spirochete antigens persist near cartilage after murine Lyme borreliosis therapy. J. Clin. Invest. 122, 2652-2660. doi: 10.1172/JCI58813

Bolz, D. D., Sundsbak, R. S., Ma, Y., Akira, S., Kirschning, C. J., Zachary, J. F., et al. (2004). MyD88 plays a unique role in host defense but not arthritis development in Lyme disease. J. Immunol. 173, 2003-2010.

Boo, K. H., and Yang, J. S. (2010). Intrinsic cellular defenses against virus infection by antiviral type I interferon. Yonsei Med. J. 51, 9-17. doi: 10.3349/ymj.2010. 51.1.9

Bowdish, D. M., Sakamoto, K., Kim, M. J., Kroos, M., Mukhopadhyay, S., Leifer, C. A., et al. (2009). MARCO, TLR2, and CD14 are required for macrophage cytokine responses to mycobacterial trehalose dimycolate and Mycobacterium tuberculosis. PLoS Pathog. 5:e1000474. doi: 10.1371/journal.ppat. 1000474

Boylan, J. A., Lawrence, K. A., Downey, J. S., and Gherardini, F. C. (2008). Borrelia burgdorferi membranes are the primary targets of reactive oxygen species. Mol. Microbiol. 68, 786-799. doi: 10.1111/j.1365-2958.2008.06204.x

Brandt, K. J., Fickentscher, C., Kruithof, E. K., and de Moerloose, P. (2013). TLR2 ligands induce NF-kappaB activation from endosomal compartments of human monocytes. PLoS ONE 8:e80743. doi: 10.1371/journal.pone.0080743

Brencicova, E., and Diebold, S. S. (2013). Nucleic acids and endosomal pattern recognition: how to tell friend from foe? Front. Cell. Infect. Microbiol. 3:37. doi: 10.3389/fcimb.2013.00037

Brigl, M., Bry, L., Kent, S. C., Gumperz, J. E., and Brenner, M. B. (2003). Mechanism of CD1d-restricted natural killer T cell activation during microbial infection. Nat. Immunol. 4, 1230-1237. doi: 10.1038/ni1002

Brinkmann, M. M., Spooner, E., Hoebe, K., Beutler, B., Ploegh, H. L., and Kim, Y. M. (2007). The interaction between the ER membrane protein UNC93B and TLR3, 7, and 9 is crucial for TLR signaling. J. Cell Biol. 177, 265-275. doi: 10.1083/jcb.200612056

Brown, C. R., Blaho, V. A., and Loiacono, C. M. (2003). Susceptibility to experimental Lyme arthritis correlates with $\mathrm{KC}$ and monocyte chemoattractant protein-1 production in joints and requires neutrophil recruitment via CXCR2. J. Immunol. 171, 893-901. doi: 10.4049/jimmunol.171.2.893

Burchill, M. A., Nardelli, D. T., England, D. M., DeCoster, D. J., Christopherson, J. A., Callister, S. M., et al. (2003). Inhibition of interleukin-17 prevents the development of arthritis in vaccinated mice challenged with Borrelia burgdorferi. Infect. Immun. 71, 3437-3442. doi: 10.1128/IAI.71.6.3437-3442.2003

Centers for Disease Control and Prevention (CDC). (2013). Three sudden cardiac deaths associated with Lyme carditis - United States, November 2012-July 2013. MMWR Morb. Mortal. Wkly. Rep. 62, 993-996.

Cervantes, J. L., Dunham-Ems, S. M., La Vake, C. J., Petzke, M. M., Sahay, B., Sellati, T. J., et al. (2011). Phagosomal signaling by Borrelia burgdorferi in human monocytes involves Toll-like receptor (TLR) 2 and TLR8 cooperativity and TLR8-mediated induction of IFN-beta. Proc. Natl. Acad. Sci. U.S.A. 108, 3683-3688. doi: 10.1073/pnas.1013776108

Cervantes, J. L., La Vake, C. J., Weinerman, B., Luu, S., O’Connell, C., Verardi, P. H., et al. (2013). Human TLR8 is activated upon recognition of Borrelia burgdorferi RNA in the phagosome of human monocytes. J. Leukoc. Biol. 94, 1231-1241. doi: $10.1189 /$ jlb.0413206

Cervantes, J. L., Weinerman, B., Basole, C., and Salazar, J. C. (2012). TLR8: the forgotten relative revindicated. Cell. Mol. Immunol. 9, 434-438. doi: 10.1038/cmi.2012.38

Chimini, G., and Chavrier, P. (2000). Function of Rho family proteins in actin dynamics during phagocytosis and engulfment. Nat. Cell Biol. 2, E191-E196. doi: $10.1038 / 35036454$

Chmielewski, T., and Tylewska-Wierzbanowska, S. (2010). Interactions between Borrelia burgdorferi and mouse fibroblasts. Pol. J. Microbiol. 59, 157-160.

Chung, Y., Chang, S. H., Martinez, G. J., Yang, X. O., Nurieva, R., Kang, H. S., et al. (2009). Critical regulation of early Th17 cell differentiation by interleukin1 signaling. Immunity 30, 576-587. doi: 10.1016/j.immuni.2009.02.007
Chung, Y., Zhang, N., and Wooten, R. M. (2013). Borrelia burgdorferi elicitedIL-10 suppresses the production of inflammatory mediators, phagocytosis, and expression of co-stimulatory receptors by murine macrophages and/or dendritic cells. PLoS ONE 8:e84980. doi: 10.1371/journal.pone.0084980

Cinco, M., Cini, B., Murgia, R., Presani, G., Prodan, M., and Perticarari, S. (2001). Evidence of involvement of the mannose receptor in adhesion of Borrelia burgdorferi to monocyte/macrophages. Infect. Immun. 69, 2743-2747. doi: 10.1128/IAI.69.4.2743-2747.2001

Cinco, M., Murgia, R., Presani, G., and Perticarari, S. (1997). Integrin CR3 mediates the binding of nonspecifically opsonized Borrelia burgdorferi to human phagocytes and mammalian cells. Infect. Immun. 65, 4784-4789.

Codolo, G., Bossi, F., Durigutto, P., Bella, C. D., Fischetti, F., Amedei, A., et al. (2013). Orchestration of inflammation and adaptive immunity in Borrelia burgdorferi-induced arthritis by neutrophil-activating protein A. Arthritis Rheum. 65, 1232-1242. doi: 10.1002/art.37875

Crandall, H., Dunn, D. M., Ma, Y., Wooten, R. M., Zachary, J. F., Weis, J. H., et al. (2006). Gene expression profiling reveals unique pathways associated with differential severity of lyme arthritis. J. Immunol. 177, 7930-7942.

Cruz, A. R., Moore, M. W., La Vake, C. J., Eggers, C. H., Salazar, J. C., and Radolf, J. D. (2008). Phagocytosis of Borrelia burgdorferi, the Lyme disease spirochete, potentiates innate immune activation and induces apoptosis in human monocytes. Infect. Immun. 76, 56-70. doi: 10.1128/IAI.01039-07

Davila, S., Hibberd, M. L., Hari Dass, R., Wong, H. E., Sahiratmadja, E., Bonnard, C., et al. (2008). Genetic association and expression studies indicate a role of toll-like receptor 8 in pulmonary tuberculosis. PLoS Genet. 4:e1000218. doi: 10.1371/journal.pgen.1000218

Deane, J. A., Pisitkun, P., Barrett, R. S., Feigenbaum, L., Town, T., Ward, J. M., et al. (2007). Control of toll-like receptor 7 expression is essential to restrict autoimmunity and dendritic cell proliferation. Immunity 27, 801-810. doi: 10.1016/j.immuni.2007.09.009

Demaria, O., Pagni, P. P., Traub, S., de Gassart, A., Branzk, N., Murphy, A. J., et al. (2010). TLR8 deficiency leads to autoimmunity in mice. J. Clin. Invest. 120, 3651-3662. doi: 10.1172/JCI42081

Dennis, V. A., Jefferson, A., Singh, S. R., Ganapamo, F., and Philipp, M. T. (2006). Interleukin-10 anti-inflammatory response to Borrelia burgdorferi, the agent of Lyme disease: a possible role for suppressors of cytokine signaling 1 and 3. Infect. Immun. 74, 5780-5789. doi: 10.1128/IAI.00678-06

Deshmukh, S. D., Kremer, B., Freudenberg, M., Bauer, S., Golenbock, D. T., and Henneke, P. (2011). Macrophages recognize streptococci through bacterial single-stranded RNA. EMBO Rep. 12, 71-76. doi: 10.1038/embor.2010.189

Diebold, S. S., Kaisho, T., Hemmi, H., Akira, S., and Reis e Sousa, C. (2004). Innate antiviral responses by means of TLR7-mediated recognition of single-stranded RNA. Science 303, 1529-1531. doi: 10.1126/science.1093616

Diebold, S. S., Massacrier, C., Akira, S., Paturel, C., Morel, Y., and Reis e Sousa, C. (2006). Nucleic acid agonists for Toll-like receptor 7 are defined by the presence of uridine ribonucleotides. Eur. J. Immunol. 36, 3256-3267. doi: 10.1002/eji.200636617

DuChateau, B. K., Munson, E. L., England, D. M., Lovrich, S. D., Callister, S. M., Jensen, J. R., et al. (1999). Macrophages interact with enriched populations of distinct $\mathrm{T}$ lymphocyte subsets for the induction of severe destructive Lyme arthritis. J. Leukoc. Biol. 65, 162-170.

Duray, P. H. (1989). Histopathology of clinical phases of human Lyme disease. Rheum. Dis. Clin. North Am. 15, 691-710.

Eberle, F., Sirin, M., Binder, M., and Dalpke, A. H. (2009). Bacterial RNA is recognized by different sets of immunoreceptors. Eur. J. Immunol. 39, 2537-2547. doi: 10.1002/eji.200838978

Filgueira, L., Nestle, F. O., Rittig, M., Joller, H. I., and Groscurth, P. (1996). Human dendritic cells phagocytose and process Borrelia burgdorferi. J. Immunol. 157, 2998-3005.

Franz, J. K., Fritze, O., Rittig, M., Keysser, G., Priem, S., Zacher, J., et al. (2001). Insights from a novel three-dimensional in vitro model of lyme arthritis: standardized analysis of cellular and molecular interactions between Borrelia burgdorferi and synovial explants and fibroblasts. Arthritis Rheum. 44, 151-162. doi: 10.1002/1529-0131(200101)44:1<151::AID-ANR19>3.0.CO;2-E

Fraser, C. M., Casjens, S., Huang, W. M., Sutton, G. G., Clayton, R., Lathigra, R., et al. (1997). Genomic sequence of a Lyme disease spirochaete, Borrelia burgdorferi. Nature 390, 580-586. doi: 10.1038/37551

Frazao, J. B., Errante, P. R., and Condino-Neto, A. (2013). Toll-like receptors' pathway disturbances are associated with increased susceptibility to infections in 
humans. Arch. Immunol. Ther. Exp. (Warsz). 61, 427-443. doi: 10.1007/s00005013-0243-0

Ganapamo, F., Dennis, V. A., and Philipp, M. T. (2003). Differential acquired immune responsiveness to bacterial lipoproteins in Lyme disease-resistant and -susceptible mouse strains. Eur. J. Immunol. 33, 1934-1940. doi: 10.1002/eji.200323655

Gangloff, M. (2012). Different dimerisation mode for TLR4 upon endosomal acidification? Trends Biochem. Sci. 37, 92-98. doi: 10.1016/j.tibs.2011.11.003

Gantier, M. P., Irving, A. T., Kaparakis-Liaskos, M., Xu, D., Evans, V. A., Cameron, P. U., et al. (2010). Genetic modulation of TLR8 response following bacterial phagocytosis. Hum. Mutat. 31, 1069-1079. doi: 10.1002/humu.21321

Garcia, R. C., Murgia, R., and Cinco, M. (2005). Complement receptor 3 binds the Borrelia burgdorferi outer surface proteins OspA and OspB in an iC3b-independent manner. Infect. Immun. 73, 6138-6142. doi: 10.1128/IAI.73.9.6138-6142.2005

Gautam, A., Dixit, S., Embers, M., Gautam, R., Philipp, M. T., Singh, S. R., et al. (2012). Different patterns of expression and of IL-10 modulation of inflammatory mediators from macrophages of Lyme disease-resistant and -susceptible mice. PLoS ONE 7:e43860. doi: 10.1371/journal.pone.0043860

Georgilis, K., Noring, R., Steere, A. C., and Klempner, M. S. (1991). Neutrophil chemotactic factors in synovial fluids of patients with Lyme disease. Arthritis Rheum. 34, 770-775. doi: 10.1002/art.1780340620

Gondolf, K. B., Mihatsch, M., Curschellas, E., Dunn, J. J., and Batsford, S. R. (1994). Induction of experimental allergic arthritis with outer surface proteins of Borrelia burgdorferi. Arthritis Rheum. 37, 1070-1077. doi: 10.1002/art.1780370713

Gosu, V., Basith, S., Kwon, O. P., and Choi, S. (2012). Therapeutic applications of nucleic acids and their analogues in Toll-like receptor signaling. Molecules 17, 13503-13529. doi: 10.3390/molecules 171113503

Greenberg, S., and Grinstein, S. (2002). Phagocytosis and innate immunity. Curr. Opin. Immunol. 14, 136-145. doi: 10.1016/S0952-7915(01)00309-0

Gross, D. M., Steere, A. C., and Huber, B. T. (1998). T helper 1 response is dominant and localized to the synovial fluid in patients with Lyme arthritis. J. Immunol. 160, 1022-1028.

Guiducci, C., Gong, M., Cepika, A. M., Xu, Z., Tripodo, C., Bennett, L., et al. (2013). RNA recognition by human TLR8 can lead to autoimmune inflammation. J. Exp. Med. 210, 2903-2919. doi: 10.1084/jem.20131044

Hartiala, P., Hytonen, J., Pelkonen, J., Kimppa, K., West, A., Penttinen, M. A., et al. (2007). Transcriptional response of human dendritic cells to Borrelia gariniidefective CD38 and CCR7 expression detected. J. Leukoc. Biol. 82, 33-43. doi: 10.1189/jlb.1106709

Hawley, K. L., Martin-Ruiz, I., Iglesias-Pedraz, J. M., Berwin, B., and Anguita, J. (2013). CD14 targets complement receptor 3 to lipid rafts during phagocytosis of Borrelia burgdorferi. Int. J. Biol. Sci. 9, 803-810. doi: 10.7150/ijbs.7136

Hawley, K. L., Olson, C. M. Jr., Iglesias-Pedraz, J. M., Navasa, N., Cervantes, J. L., Caimano, M. J., et al. (2012). CD14 cooperates with complement receptor 3 to mediate MyD88-independent phagocytosis of Borrelia burgdorferi. Proc. Natl. Acad. Sci. U.S.A. 109, 1228-1232. doi: 10.1073/pnas.1112078109

Heil, F., Hemmi, H., Hochrein, H., Ampenberger, F., Kirschning, C., Akira, S. et al. (2004). Species-specific recognition of single-stranded RNA via toll-like receptor 7 and 8. Science 303, 1526-1529. doi: 10.1126/science.1093620

Hellwage, J., Meri, T., Heikkila, T., Alitalo, A., Panelius, J., Lahdenne, P., et al. (2001). The complement regulator factor $\mathrm{H}$ binds to the surface protein OspE of Borrelia burgdorferi. J. Biol. Chem. 276, 8427-8435. doi 10.1074/jbc.M007994200

Henault, J., Martinez, J., Riggs, J. M., Tian, J., Mehta, P., Clarke, L., et al. (2012). Noncanonical autophagy is required for type I interferon secretion in response to DNA-immune complexes. Immunity 37, 986-997. doi: 10.1016/j.immuni.2012.09.014

Higgs, H. N., and Pollard, T. D. (2001). Regulation of actin filament network formation through ARP2/3 complex: activation by a diverse array of proteins. Annu. Rev. Biochem. 70, 649-676. doi: 10.1146/annurev.biochem.70.1.649

Hornung, V., Rothenfusser, S., Britsch, S., Krug, A., Jahrsdorfer, B., Giese, T., et al. (2002). Quantitative expression of toll-like receptor 1-10 mRNA in cellular subsets of human peripheral blood mononuclear cells and sensitivity to CpG oligodeoxynucleotides. J. Immunol. 168, 4531-4537. doi: 10.4049/jimmunol. 168.9.453
Horwitz, M. A. (1984). Phagocytosis of the Legionnaires' disease bacterium (Legionella pneumophila) occurs by a novel mechanism: engulfment within a pseudopod coil. Cell 36, 27-33. doi: 10.1016/0092-8674(84)90070-9

Hovius, J. W., Bijlsma, M. F., van der Windt, G. J., Wiersinga, W. J., Boukens, B. J., Coumou, J., et al. (2009). The urokinase receptor (uPAR) facilitates clearance of Borrelia burgdorferi. PLoS Pathog. 5:e1000447. doi: 10.1371/journal. ppat. 1000447

Humphries, M. J. (2000). Integrin structure. Biochem. Soc. Trans. 28, 311-339. doi: 10.1042/0300-5127:0280311

Itoh, H., Tatematsu, M., Watanabe, A., Iwano, K., Funami, K., Seya, T., et al. (2011). UNC93B1 physically associates with human TLR8 and regulates TLR8mediated signaling. PLoS ONE 6:e28500. doi: 10.1371/journal.pone.0028500

Jockel, S., Nees, G., Sommer, R., Zhao, Y., Cherkasov, D., Hori, H., et al. (2012). The 2'-O-methylation status of a single guanosine controls transfer RNA-mediated Toll-like receptor 7 activation or inhibition. J. Exp. Med. 209, 235-241. doi: 10.1084/jem.20111075

Jordo, E. D., Wermeling, F., Chen, Y., and Karlsson, M. C. (2011). Scavenger receptors as regulators of natural antibody responses and B cell activation in autoimmunity. Mol. Immunol. 48, 1307-1318. doi: 10.1016/j.molimm.2011.01.010

Jozefowski, S., Sulahian, T. H., Arredouani, M., and Kobzik, L. (2006). Role of scavenger receptor MARCO in macrophage responses to $\mathrm{CpG}$ oligodeoxynucleotides. J. Leukoc. Biol. 80, 870-879. doi: 10.1189/jlb.0705357

Kariko, K., Buckstein, M., Ni, H., and Weissman, D. (2005). Suppression of RNA recognition by Toll-like receptors: the impact of nucleoside modification and the evolutionary origin of RNA. Immunity 23, 165-175. doi: 10.1016/j.immuni.2005.06.008

Kawai, T., and Akira, S. (2010). The role of pattern-recognition receptors in innate immunity: update on Toll-like receptors. Nat. Immunol. 11, 373-384. doi: 10.1038/ni.1863

Kean, I. R., and Irvine, K. L. (2013). Lyme disease: aetiopathogenesis, factors for disease development and control. Inflammopharmacology 21, 101-111. doi: 10.1007/s10787-012-0156-2

Kenny, E. F., Talbot, S., Gong, M., Golenbock, D. T., Bryant, C. E., and O’Neill, L. A. (2009). MyD88 adaptor-like is not essential for TLR2 signaling and inhibits signaling by TLR3. J. Immunol. 183, 3642-3651. doi: 10.4049/jimmunol.0901140

Kim, Y. M., Brinkmann, M. M., Paquet, M. E., and Ploegh, H. L. (2008). UNC93B1 delivers nucleotide-sensing toll-like receptors to endolysosomes. Nature 452, 234-238. doi: 10.1038/nature06726

Kochi, S. K., and Johnson, R. C. (1988). Role of immunoglobulin G in killing of Borrelia burgdorferi by the classical complement pathway. Infect. Immun. 56, 314-321.

Koski, G. K., Kariko, K., Xu, S., Weissman, D., Cohen, P. A., and Czerniecki, B. J. (2004). Cutting edge: innate immune system discriminates between RNA containing bacterial versus eukaryotic structural features that prime for high-level IL-12 secretion by dendritic cells. J. Immunol. 172, 3989-3993. doi: 10.4049/ jimmunol.172.7.3989

Kraiczy, P., Hellwage, J., Skerka, C., Becker, H., Kirschfink, M., Simon, M. M., et al. (2004). Complement resistance of Borrelia burgdorferi correlates with the expression of BbCRASP-1, a novel linear plasmid-encoded surface protein that interacts with human factor $\mathrm{H}$ and FHL-1 and is unrelated to Erp proteins J. Biol. Chem. 279, 2421-2429. doi: 10.1074/jbc.M308343200

Kraiczy, P., Skerka, C., Kirschfink, M., Brade, V., and Zipfel, P. F. (2001). Immune evasion of Borrelia burgdorferi by acquisition of human complement regulators FHL-1/reconectin and Factor, H. Eur. J. Immunol. 31, 1674-1684. doi: 10.1002/ 1521-4141(200106)31:6<1674::AID-IMMU1674>3.0.CO;2-2

Krause, P. J., and Bockenstedt, L. K. (2013). Cardiology patient pages. Lyme disease and the heart. Circulation 127, e451-e454. doi: 10.1161/CIRCULATIONAHA.112.101485

Kuhlow, C. J., Garcia-Monco, J. C., Coleman, J. L., and Benach, J. L. (2005). Murine microglia are effective phagocytes for Borrelia burgdorferi. J. Neuroimmunol. 168, 183-187. doi: 10.1016/j.jneuroim.2005.06.030

Latz, E., Schoenemeyer, A., Visintin, A., Fitzgerald, K. A., Monks, B. G., Knetter, C. F., et al. (2004). TLR9 signals after translocating from the ER to CpG DNA in the lysosome. Nat. Immunol. 5, 190-198. doi: 10.1038/ni1028

Lazarus, J. J., Kay, M. A., McCarter, A. L., and Wooten, R. M. (2008). Viable Borrelia burgdorferi enhances interleukin-10 production and suppresses activation of murine macrophages. Infect. Immun. 76, 1153-1162. doi: 10.1128/IAI.01404-07 
Lee, B. L., Moon, J. E., Shu, J. H., Yuan, L., Newman, Z. R., Schekman, R., et al. (2013). UNC93B1 mediates differential trafficking of endosomal TLRs. Elife 2:e00291. doi: 10.7554/eLife.00291

Lee, W. Y., Moriarty, T. J., Wong, C. H., Zhou, H., Strieter, R. M., van Rooijen, N., et al. (2010). An intravascular immune response to Borrelia burgdorferi involves Kupffer cells and iNKT cells. Nat. Immunol. 11, 295-302. doi: 10.1038/ni.1855

Levi, T., Kilpatrick, A. M., Mangel, M., and Wilmers, C. C. (2012). Deer, predators, and the emergence of Lyme disease. Proc. Natl. Acad. Sci. U.S.A. 109, 10942-10947. doi: 10.1073/pnas.1204536109

Li, X., McHugh, G. A., Damle, N., Sikand, V. K., Glickstein, L., and Steere, A. C. (2011). Burden and viability of Borrelia burgdorferi in skin and joints of patients with erythema migrans or lyme arthritis. Arthritis Rheum. 63, 2238-2247. doi: 10.1002/art.30384

Lin, Y. T., Verma, A., and Hodgkinson, C. P. (2012). Toll-like receptors and human disease: lessons from single nucleotide polymorphisms. Curr. Genomics 13, 633-645. doi: 10.2174/138920212803759712

Linder, S., Heimerl, C., Fingerle, V., Aepfelbacher, M., and Wilske, B. (2001). Coiling phagocytosis of Borrelia burgdorferi by primary human macrophages is controlled by CDC42Hs and Racl and involves recruitment of Wiskott-Aldrich syndrome protein and Arp2/3 complex. Infect. Immun. 69, 1739-1746. doi: 10.1128/IAI.69.3.1739-1746.2001

Liu, J., Xu, C., Hsu, L. C., Luo, Y., Xiang, R., and Chuang, T. H. (2010). A five-amino-acid motif in the undefined region of the TLR8 ectodomain is required for species-specific ligand recognition. Mol. Immunol. 47, 1083-1090. doi: 10.1016/j.molimm.2009.11.003

Liu, N., Montgomery, R. R., Barthold, S. W., and Bockenstedt, L. K. (2004). Myeloid differentiation antigen 88 deficiency impairs pathogen clearance but does not alter inflammation in Borrelia burgdorferi-infected mice. Infect. Immun. 72, 3195-3203. doi: 10.1128/IAI.72.6.3195-3203.2004

Love, A. C., Schwartz, I., and Petzke, M. M. (2014). Borrelia burgdorferi RNA induces type I and type III interferons via TLR7 and contributes to the production of NF-kappaB-dependent cytokines. Infect Immun. doi: 10.1128/IAI. 01617-14. [Epub ahead of print].

Ma, Y., Seiler, K. P., Eichwald, E. J., Weis, J. H., Teuscher, C., and Weis, J. J. (1998). Distinct characteristics of resistance to Borrelia burgdorferi-induced arthritis in C57BL/6N mice. Infect. Immun. 66, 161-168.

Maden, B. E., and Hughes, J. M. (1997). Eukaryotic ribosomal RNA: the recent excitement in the nucleotide modification problem. Chromosoma 105, 391-400. doi: 10.1007/BF02510475

Mancuso, G., Gambuzza, M., Midiri, A., Biondo, C., Papasergi, S., Akira, S., et al. (2009). Bacterial recognition by TLR7 in the lysosomes of conventional dendritic cells. Nat. Immunol. 10, 587-594. doi: 10.1038/ni.1733

Mantovani, A., Cassatella, M. A., Costantini, C., and Jaillon, S. (2011). Neutrophils in the activation and regulation of innate and adaptive immunity. Nat. Rev. Immunol. 11, 519-531. doi: 10.1038/nri3024

Mason, L. M., Veerman, C. C., Geijtenbeek, T. B., and Hovius, J. W. (2014). Menage a trois: Borrelia, dendritic cells, and tick saliva interactions. Trends Parasitol. 30, 95-103. doi: 10.1016/j.pt.2013.12.003

McGettrick, A. F., and O'Neill, L. A. (2010). Localisation and trafficking of Toll-like receptors: an important mode of regulation. Curr. Opin. Immunol. 22, 20-27. doi: 10.1016/j.coi.2009.12.002

Miller, J. C., Ma, Y., Bian, J., Sheehan, K. C., Zachary, J. F., Weis, J. H., et al. (2008b). A critical role for type I IFN in arthritis development following Borrelia burgdorferi infection of mice. J. Immunol. 181, 8492-8503.

Miller, J. C., Ma, Y., Crandall, H., Wang, X., and Weis, J. J. (2008a). Gene expression profiling provides insights into the pathways involved in inflammatory arthritis development: murine model of Lyme disease. Exp. Mol. Pathol. 85, 20-27. doi: 10.1016/j.yexmp.2008.03.004

Montgomery, R. R., Nathanson, M. H., and Malawista, S. E. (1994). Fc- and nonFc-mediated phagocytosis of Borrelia burgdorferi by macrophages. J. Infect. Dis. 170, 890-893. doi: 10.1093/infdis/170.4.890

Moore, M. W., Cruz, A. R., LaVake, C. J., Marzo, A. L., Eggers, C. H., Salazar, J. C., et al. (2007). Phagocytosis of Borrelia burgdorferi and Treponema pallidum potentiates innate immune activation and induces gamma interferon production. Infect. Immun. 75, 2046-2062. doi: 10.1128/IAI.01666-06

Mosser, D. M., and Edwards, J. P. (2008). Exploring the full spectrum of macrophage activation. Nat. Rev. Immunol. 8, 958-969. doi: 10.1038/nri2448
Mukhopadhyay, S., and Gordon, S. (2004). The role of scavenger receptors in pathogen recognition and innate immunity. Immunobiology 209, 39-49. doi: 10.1016/j.imbio.2004.02.004

Naj, X., Hoffmann, A. K., Himmel, M., and Linder, S. (2013). The formins FMNL1 and mDial regulate coiling phagocytosis of Borrelia burgdorferi by primary human macrophages. Infect. Immun. 81, 1683-1695. doi: 10.1128/IAI.01411-12

Napirei, M., Karsunky, H., Zevnik, B., Stephan, H., Mannherz, H. G., and Moroy, T. (2000). Features of systemic lupus erythematosus in Dnase1-deficient mice. Nat. Genet. 25, 177-181. doi: 10.1038/76032

Nardelli, D. T., Callister, S. M., and Schell, R. F. (2008). Lyme arthritis: current concepts and a change in paradigm. Clin. Vaccine Immunol. 15, 21-34. doi: 10.1128/CVI.00330-07

Netea, M. G., Wijmenga, C., and O'Neill, L. A. (2012). Genetic variation in Toll-like receptors and disease susceptibility. Nat. Immunol. 13, 535-542. doi: 10.1038/ni.2284

Olson, C. M. Jr., Bates, T. C., Izadi, H., Radolf, J. D., Huber, S. A., Boyson, J. E., et al. (2009). Local production of IFN-gamma by invariant NKT cells modulates acute Lyme carditis. J. Immunol. 182, 3728-3734. doi: 10.4049/jimmunol.0804111

Oosting, M., van de Veerdonk, F. L., Kanneganti, T. D., Sturm, P., Verschueren, I., Berende, A., et al. (2011). Borrelia species induce inflammasome activation and IL-17 production through a caspase-1-dependent mechanism. Eur. J. Immunol. 41, 172-181. doi: 10.1002/eji.201040385

Peiser, L., Gough, P. J., Kodama, T., and Gordon, S. (2000). Macrophage class A scavenger receptor-mediated phagocytosis of Escherichia coli: role of cell heterogeneity, microbial strain, and culture conditions in vitro. Infect. Immun. 68, 1953-1963. doi: 10.1128/IAI.68.4.1953-1963.2000

Petnicki-Ocwieja, T., Chung, E., Acosta, D. I., Ramos, L. T., Shin, O. S., Ghosh, S., et al. (2013). TRIF mediates Toll-like receptor 2-dependent inflammatory responses to Borrelia burgdorferi. Infect. Immun. 81, 402-410. doi: 10.1128/IAI.00890-12

Petzke, M. M., Brooks, A., Krupna, M. A., Mordue, D., and Schwartz, I. (2009). Recognition of Borrelia burgdorferi, the Lyme disease spirochete, by TLR7 and TLR9 induces a type I IFN response by human immune cells. J. Immunol. 183, 5279-5292. doi: 10.4049/jimmunol.0901390

Picha, D., Moravcova, L., Holeckova, D., Zd'arsky, E., Valesova, M., Maresova, V., et al. (2008). Examination of specific DNA by PCR in patients with different forms of Lyme borreliosis. Int. J. Dermatol. 47, 1004-1010. doi: 10.1111/j.13654632.2008.03709.x

Picha, D., Moravcova, L., Vanousova, D., Hercogova, J., and Blechova, Z. (2014). DNA persistence after treatment of Lyme borreliosis. Folia Microbiol. (Praha) 59, 115-125. doi: 10.1007/s12223-013-0272-4

Pisitkun, P., Deane, J. A., Difilippantonio, M. J., Tarasenko, T., Satterthwaite, A B., and Bolland, S. (2006). Autoreactive B cell responses to RNA-related antigens due to TLR7 gene duplication. Science 312, 1669-1672. doi: 10.1126/science. 1124978

Radolf, J. D., Caimano, M. J., Stevenson, B., and Hu, L. T. (2012). Of ticks, mice and men: understanding the dual-host lifestyle of Lyme disease spirochaetes. Nat. Rev. Microbiol. 10, 87-99. doi: 10.1038/nrmicro2714

Radolf, J. D., and Samuels, D. S. (2010). "Lyme Disease in humans," in Borrelia: Molecular Biology, Host Interaction, and Pathogenesis, eds D. D. Samuels and J. D. Radolf (Norfolk: Caister Academic Press), 487-533.

Rittig, M. G., Jagoda, J. C., Wilske, B., Murgia, R., Cinco, M., Repp, R., et al. (1998). Coiling phagocytosis discriminates between different spirochetes and is enhanced by phorbol myristate acetate and granulocyte-macrophage colonystimulating factor. Infect. Immun. 66, 627-635.

Rittig, M. G., Krause, A., Haupl, T., Schaible, U. E., Modolell, M., Kramer, M. D., et al. (1992). Coiling phagocytosis is the preferential phagocytic mechanism for Borrelia burgdorferi. Infect. Immun. 60, 4205-4212.

Roessner, K., Wolfe, J., Shi, C., Sigal, L. H., Huber, S., and Budd, R. C. (2003) High expression of Fas ligand by synovial fluid-derived gamma delta T cells in Lyme arthritis. J. Immunol. 170, 2702-2710. doi: 10.4049/jimmunol.170. 5.2702

Sahay, B., Patsey, R. L., Eggers, C. H., Salazar, J. C., Radolf, J. D., and Sellati, T. J. (2009). CD14 signaling restrains chronic inflammation through induction of p38-MAPK/SOCS-dependent tolerance. PLoS Pathog. 5:e1000687. doi: 10.1371/journal.ppat.1000687 
Saitoh, S., and Miyake, K. (2009). Regulatory molecules required for nucleotidesensing Toll-like receptors. Immunol. Rev. 227, 32-43. doi: 10.1111/j.1600065X.2008.00729.x

Salazar, J. C., Duhnam-Ems, S., La Vake, C., Cruz, A. R., Moore, M. W., Caimano, M. J., et al. (2009). Activation of human monocytes by live Borrelia burgdorferi generates TLR2-dependent and -independent responses which include induction of IFN-beta. PLoS Pathog. 5:e1000444. doi: 10.1371/journal.ppat.1000444

Salazar, J. C., Pope, C. D., Sellati, T. J., Feder, H. M. Jr., Kiely, T. G., Dardick, K. R., et al. (2003). Coevolution of markers of innate and adaptive immunity in skin and peripheral blood of patients with erythema migrans. J. Immunol. 171, 2660-2670. doi: 10.4049/jimmunol.171.5.2660

Sander, L. E., Davis, M. J., Boekschoten, M. V., Amsen, D., Dascher, C. C., Ryffel, B., et al. (2011). Detection of prokaryotic mRNA signifies microbial viability and promotes immunity. Nature 474, 385-389. doi: 10.1038/nature 10072

Sasai, M., Linehan, M. M., and Iwasaki, A. (2010). Bifurcation of Toll-like receptor 9 signaling by adaptor protein 3 . Science 329, 1530-1534. doi: 10.1126/science. 1187029

Schutzer, S. E., Fraser-Liggett, C. M., Casjens, S. R., Qiu, W. G., Dunn, J. J., Mongodin, E. F., et al. (2011). Whole-genome sequences of thirteen isolates of Borrelia burgdorferi. J. Bacteriol. 193, 1018-1020. doi: 10.1128/JB.01158-10

Schwartz, D. A., and Cook, D. N. (2005). Polymorphisms of the Toll-like receptors and human disease. Clin. Infect. Dis. 41(Suppl. 7), S403-S407. doi: $10.1086 / 431985$

Shi, Y., Zhang, J., Mullin, M., Dong, B., Alberts, A. S., and Siminovitch, K. A. (2009). The mDial formin is required for neutrophil polarization, migration, and activation of the LARG/RhoA/ROCK signaling axis during chemotaxis. J. Immunol. 182, 3837-3845. doi: 10.4049/jimmunol.0803838

Shin, J. J., Glickstein, L. J., and Steere, A. C. (2007). High levels of inflammatory chemokines and cytokines in joint fluid and synovial tissue throughout the course of antibiotic-refractory lyme arthritis. Arthritis Rheum. 56, 1325-1335. doi: 10.1002/art.22441

Shin, O. S., Isberg, R. R., Akira, S., Uematsu, S., Behera, A. K., and Hu, L. T. (2008). Distinct roles for MyD88 and Toll-like receptors 2, 5, and 9 in phagocytosis of Borrelia burgdorferi and cytokine induction. Infect. Immun. 76, 2341-2351. doi: 10.1128/IAI.01600-07

Shin, O. S., Miller, L. S., Modlin, R. L., Akira, S., Uematsu, S., and Hu, L. T. (2009). Downstream signals for MyD88-mediated phagocytosis of Borrelia burgdorferi can be initiated by TRIF and are dependent on PI3K. J. Immunol. 183, 491-498. doi: 10.4049/jimmunol.0900724

Sonderegger, F. L., Ma, Y., Maylor-Hagan, H., Brewster, J., Huang, X., Spangrude, G. J., et al. (2012). Localized production of IL-10 suppresses early inflammatory cell infiltration and subsequent development of IFN-gamma-mediated Lyme arthritis. J. Immunol. 188, 1381-1393. doi: 10.4049/jimmunol.1102359

Steere, A. C. (2012). Reinfection versus relapse in Lyme disease. N. Engl. J. Med. 367, 1950-1951. doi: 10.1056/NEJMe1211361

Steere, A. C., Schoen, R. T., and Taylor, E. (1987). The clinical evolution of Lyme arthritis. Ann. Intern. Med. 107, 725-731. doi: 10.7326/0003-4819-107-5-725

Strle, K., Drouin, E. E., Shen, S., El Khoury, J., McHugh, G., Ruzic-Sabljic, E., et al. (2009). Borrelia burgdorferi stimulates macrophages to secrete higher levels of cytokines and chemokines than Borrelia afzelii or Borrelia garinii. J. Infect. Dis. 200, 1936-1943. doi: 10.1086/648091

Suhonen, J., Komi, J., Soukka, J., Lassila, O., and Viljanen, M. K. (2003). Interaction between Borrelia burgdorferi and immature human dendritic cells. Scand. J. Immunol. 58, 67-75. doi: 10.1046/j.1365-3083.2003.01284.x

Takayama, K., Rothenberg, R. J., and Barbour, A. G. (1987). Absence of lipopolysaccharide in the Lyme disease spirochete, Borrelia burgdorferi. Infect. Immun. 55, 2311-2313.

Thelen, T., Hao, Y., Medeiros, A. I., Curtis, J. L., Serezani, C. H., Kobzik, L., et al. (2010). The class A scavenger receptor, macrophage receptor with collagenous structure, is the major phagocytic receptor for Clostridium sordellii expressed by human decidual macrophages. J. Immunol. 185, 4328-4335. doi: 10.4049/jimmunol.1000989

Theofilopoulos, A. N., Kono, D. H., Beutler, B., and Baccala, R. (2011). Intracellular nucleic acid sensors and autoimmunity. J. Interferon Cytokine Res. 31, 867-886. doi: 10.1089/jir.2011.0092

Tupin, E., Benhnia, M. R., Kinjo, Y., Patsey, R., Lena, C. J., Haller, M. C., et al. (2008). NKT cells prevent chronic joint inflammation after infection with Borrelia burgdorferi. Proc. Natl. Acad. Sci. U.S.A. 105, 19863-19868. doi: 10.1073/pnas.0810519105

Underhill, D. M., and Ozinsky, A. (2002). Phagocytosis of microbes: complexity in action. Annu. Rev. Immunol. 20, 825-852. doi: 10.1146/annurev.immunol.20. 103001.114744

Vance, R. E., Isberg, R. R., and Portnoy, D. A. (2009). Patterns of pathogenesis: discrimination of pathogenic and nonpathogenic microbes by the innate immune system. Cell Host Microbe. 6, 10-21. doi: 10.1016/j.chom.2009.06.007

Vincent, M. S., Roessner, K., Lynch, D., Wilson, D., Cooper, S. M., Tschopp, J., et al. (1996). Apoptosis of Fashigh CD4+ synovial T cells by borrelia-reactive Fasligand(high) gamma delta T cells in Lyme arthritis. J. Exp. Med. 184, 2109-2117. doi: 10.1084/jem.184.6.2109

Wang, J., Shao, Y., Bennett, T. A., Shankar, R. A., Wightman, P. D., and Reddy, L. G. (2006). The functional effects of physical interactions among Toll-like receptors 7, 8, and 9. J. Biol. Chem. 281, 37427-37434. doi: 10.1074/jbc.M605311200

Weiss, J. J. (2010). “Host response," in Borrelia: Molecular Biology, Host Interaction, and Pathogenesis, eds D. S. Samuels and J. D. Radolf (Norfolk: Caister Academic Press), 413-441.

Wooten, R. M., and Weis, J. J. (2001). Host-pathogen interactions promoting inflammatory Lyme arthritis: use of mouse models for dissection of disease processes. Curr. Opin. Microbiol. 4, 274-279. doi: 10.1016/S1369-5274(00)00202-2

Yang, X., Qin, J., Promnares, K., Kariu, T., Anderson, J. F., and Pal, U. (2013). Novel microbial virulence factor triggers murine lyme arthritis. J. Infect. Dis. 207, 907-918. doi: 10.1093/infdis/jis930

Yasutomo, K., Horiuchi, T., Kagami, S., Tsukamoto, H., Hashimura, C., Urushihara, M., et al. (2001). Mutation of DNASE1 in people with systemic lupus erythematosus. Nat. Genet. 28, 313-314. doi: 10.1038/91070

Yates, R. M., and Russell, D. G. (2005). Phagosome maturation proceeds independently of stimulation of toll-like receptors 2 and 4. Immunity 23, 409-417. doi: 10.1016/j.immuni.2005.09.007

Zheng, L., Zhang, Z., Yu, C., and Yang, C. (2010). Expression of Toll-like receptors 7, 8, and 9 in primary Sjogren's syndrome. Oral Surg. Oral Med. Oral Pathol. Oral Radiol. Endod. 109, 844-850. doi: 10.1016/j.tripleo.2010.01.006

Conflict of Interest Statement: The authors declare that the research was conducted in the absence of any commercial or financial relationships that could be construed as a potential conflict of interest.

Received: 12 March 2014; accepted: 09 April 2014; published online: 20 May 2014. Citation: Cervantes JL, Hawley KL, Benjamin SJ, Weinerman B, Luu SM and Salazar JC (2014) Phagosomal TLR signaling upon Borrelia burgdorferi infection. Front. Cell. Infect. Microbiol. 4:55. doi: 10.3389/fcimb.2014.00055

This article was submitted to the journal Frontiers in Cellular and Infection Microbiology.

Copyright (C) 2014 Cervantes, Hawley, Benjamin, Weinerman, Luu and Salazar. This is an open-access article distributed under the terms of the Creative Commons Attribution License (CC BY). The use, distribution or reproduction in other forums is permitted, provided the original author(s) or licensor are credited and that the original publication in this journal is cited, in accordance with accepted academic practice. No use, distribution or reproduction is permitted which does not comply with these terms. 